\title{
The soyabean isoflavone genistein modulates endothelial cell behaviour
}

\author{
Marisa J. Sandoval ${ }^{1}$, Pablo H. Cutini ${ }^{1,2}$, María Belén Rauschemberger ${ }^{1,2}$ and Virginia L. Massheimer ${ }^{1,2 *}$ \\ ${ }^{1}$ Departamento de Biología, Bioquímica y Farmacia, Cátedra de Bioquímica Clínica II, Universidad Nacional del Sur, \\ San Juan 670, B8000ICN Bahía Blanca, Argentina \\ ${ }^{2}$ Consejo Nacional de Investigaciones Científicas y Técnicas (CONICET), Rivadavia 1910, Buenos Aires, Argentina
}

(Received 2 November 2009 - Revised 6 January 2010 - Accepted 20 January 2010 - First published online 1 March 2010)

The aim of the present study was to investigate the direct action of the phyto-oestrogen genistein (Gen) on vascular endothelial behaviour, either in the presence or absence of proinflammatory agents. In rat aortic endothelial cell (EC) cultures, $24 \mathrm{~h}$ of treatment with Gen significantly increased cell proliferation in a wide range of concentration (0.001-10 nM). This mitogenic action was prevented by the oestrogen receptor (ER) antagonist ICI 182780 or by the presence of the specific NO synthase inhibitor L-nitro-arginine methyl ester. When monocytes adhesion to EC was measured, Gen partially attenuated leucocyte adhesion not only under basal conditions, but also in the presence of bacterial lipopolysaccharides (LPS). The effect of the phyto-oestrogen on the expression of EC adhesion molecules was evaluated. Gen down-regulated the enhancement in mRNA levels of E-selectin, vascular cell adhesion molecule-1 and P-selectin elicited by the proinflammatory agent bacterial LPS. The regulation of EC programmed death induced by the isoflavone was also demonstrated. Incubation with $10 \mathrm{nM}$ Gen prevented DNA fragmentation induced by the apoptosis inductor $\mathrm{H}_{2} \mathrm{O}_{2}$. The results presented suggest that Gen would exert a protective effect on vascular endothelium, due to its regulatory action on endothelial proliferation, apoptosis and leucocyte adhesion, events that play a critical role in vascular diseases. The molecular mechanism displayed by the phyto-oestrogen involved the participation of the ER and the activation of the NO pathway.

Phyto-oestrogens: Genistein: Apoptosis: Monocyte adhesion: Proliferation

Under physiological conditions, vascular endothelium contributes to vascular homeostasis by monitoring haemostasis, vascular tone, endothelial permeability and media smooth muscle cell migration ${ }^{(1)}$. Leucocyte binding to the endothelium is a common feature of several inflammatory and immunological disorders. Polymorphonuclear leucocytes bind to the endothelium in acute inflammation; meanwhile, monocytes adhesion occurs predominantly in atherosclerosis.

Atherosclerosis is an inflammatory process started by monocyte adhesion and migration into the vascular wall. Vascular endothelium is central in its initiation and propagation ${ }^{(2,3)}$. Leucocyte recruitment into the vascular wall is a multistep process that subsequently includes leucocyte rolling, firm adhesion and transmigration. Different leucocyte subsets and diverse endothelial cell (EC) adhesion molecules are involved. Selectins (L-selectin; P-selectin; E-selectin) are responsible for initial stages of cell rolling. Integrins participate in firm adhesion, and Ig super family mediates transmigration step. Ig super family includes vascular cell adhesion molecule (VCAM-1), intercellular adhesion molecules (ICAM-1; ICAM-2; ICAM-3) and platelet EC adhesion molecule- $1^{(4,5)}$.

Atherogenesis is also associated with an increase of EC turnover, and it may also result in an accelerated EC apoptosis ${ }^{(6)}$. Apoptosis of EC may be caused by oxidative stress, local inflammatory mediators or by cytolytic attack of activated killer $\mathrm{T}$ cells, cytokines and oxidised $\mathrm{LDL}^{(7)}$.

Sex steroids hormones exert diverse effects on vascular system, inducing rapid vasodilatation, anti-thrombotic effect and attenuation of atherosclerosis disease ${ }^{(8)}$. Oestradiol reduces endothelial activation and leucocyte adhesion molecules expression, and it decreases leucocyte binding to vascular wall ${ }^{(9)}$.

Phyto-oestrogens may improve vascular function having favourable effects on surrogate cardiovascular risk markers $^{(10)}$. The phyto-oestrogen family includes lignans and flavonoids such as genistein (Gen) and daidzein, which are mainly present in soya beans and soya-derived foods ${ }^{(11)}$. Gen shares structural features with the potent oestrogen $17-\beta$-oestradiol, particularly the phenolic ring, which confers ability to bind to oestrogen receptor (ER) and sex hormones binding protein ${ }^{(12,13)}$. Gen can exert both oestrogenic and anti-oestrogenic activity. It has been reported that the isoflavone could exert a dual mechanism of action dependent on the dose employed. Below $20 \mu \mathrm{M}$, Gen acts via an ER-dependent pathway involving extracellular signal-regulated kinase $1 / 2$ activation, and at higher concentration $(>25 \mu \mathrm{M})$ its effects are attributed to its tyrosine kinase inhibitor activity ${ }^{(14)}$. In postmenopausal women, results of epidemiological studies have suggested that high dietary intake of isoflavones may

Abbreviations: DMEM, Dulbecco's modified Eagle's medium; EC, endothelial cell; ER, oestrogen receptor; FCS, fetal calf serum; Gen, genistein; LPS,

lipopolysaccharides; NOS, NO synthase; PBM, peripheral blood monocyte; VCAM-1, vascular cell adhesion molecule.

* Corresponding author: Dr Virginia Massheimer, fax +54 291 4595130, email massheim@uns.edu.ar 
contribute to a low incidence of high prevalent chronic diseases such as osteoporosis, hormone-related cancers and $\mathrm{CVD}^{(15)}$. Although potential effects of isoflavones on human vascular health have widely been investigated in the last decade, the mechanism of action of Gen in vascular wall remains unclear. Dietary supplementation with Gen would have beneficial effects on vascular tone and prevention of atherosclerosis $^{(16)}$.

We have previously shown that Gen exhibits anti-platelet activity through its direct action on vascular tissue ${ }^{(17)}$. In rat aortic strips isolated from fertile female Wistar rats, Gen $(0 \cdot 1-100 \mathrm{nM})$ non-genomically stimulates NO synthase (NOS) and cyclo-oxygenase activities via the ER-dependent pathway. The enhancement of NO and prostacyclin release induced by the isoflavone inhibit platelet activation and aggregation. These effects were also detected in rats deprived of ovarian function ${ }^{(17)}$.

In the present work, we study the direct action of Gen at EC level. We evaluate whether submicromolar concentration of the phyto-oestrogen would modulate endothelial proliferation, monocyte adhesion and cellular apoptosis either in the presence or absence of proinflammatory agents.

\section{Materials and methods}

\section{Materials}

$\left[{ }^{3} \mathrm{H}\right]$ Thymidine was purchased from New England Nuclear (Chicago, Des Plaines, IL, USA). Griess reaction solutions were purchased from Britania Laboratories (Buenos Aires, Argentina). Trypsin/EDTA $(10 \times)$, L-glutamine $(100 \times)$, amphotericin B $(0.25 \mathrm{mg} / \mathrm{ml})$, penicillin/streptomycin $(100 \times)$ and fetal bovine serum were obtained from PAA Laboratories (Pasching, Austria). RT-PCR RNA kit and Superscript III CellsDirect cDNA synthesis system were purchased from Invitrogen (Carlsbad, CA, USA). Gen, Dulbecco's modified Eagle's medium (DMEM), lipopolysaccharides (LPS from Escherichia coli 0127) and all other reagents were purchased from Sigma Chemical Company (St Louis, MO, USA).

\section{Animals}

Sexually mature female Wistar rats (3-5 weeks old) were employed. All animal work was performed at the Unit of Animal Care belonging to the Biology, Biochemistry and Pharmacy's Department of the University. The Animal Care Use Committee approved the protocol used.

\section{Endothelial cells cultures}

EC were obtained from aortic rings explants isolated from 3-5-weeks-old Wistar female rats, as previously reported ${ }^{(18,19)}$. Briefly, the full length thoracic aorta was aseptically removed, and then cut into ring segments $(2 \mathrm{~mm})$. Ring explants were seeded in a $60 \mathrm{~mm}$ matrix-coated Petri dishes (NUNC) containing DMEM supplemented with $10 \%$ fetal calf serum (FCS), $60 \mu \mathrm{g} / \mathrm{ml}$ penicillin, $100 \mu \mathrm{g} / \mathrm{ml}$ streptomycin, $2.5 \mu \mathrm{g} / \mathrm{ml}$ amphotericin-B and $2 \mathrm{mM}$ L-glutamine, and they were incubated at $37^{\circ} \mathrm{C}$ in $5 \% \mathrm{CO}_{2}$ atmosphere. After $5 \mathrm{~d}$ of culture, ring explants were removed, and the remaining cells were allowed to reach confluence. The identity of the $\mathrm{EC}^{(20)}$ was determined as follows: (a) by phase-contrast microscope observation of the characteristic morphology of cobblestone-shaped growth in confluent monolayers; (b) by positive immunocytochemistry reactivity to factor VIII and to anti-vimentin, clone V9 using DakoCytomation EnVision system; (c) by the bioability to synthesise NO. Cells from passages 2-7 were used for all experiments.

\section{Measurement of nitric oxide production}

EC were seeded on twenty-four multi-well (NUNC) plates at a density of $4 \times 10^{4}$ cells $/ \mathrm{cm}^{2}$ and allowed to grow to $90 \%$ confluence, and then exposed to Gen for 5-30 min. Respectively control (vehicle alone) was also processed. Nitrites were measured in the incubation media as a stable and nonvolatile breakdown product of the NO released, employing Griess reaction $^{(21)}$. Cells were dissolved in $\mathrm{NaOH}$, and protein content was measured ${ }^{(22)}$. The results were expressed as nmol of nitrites per $\mathrm{mg}$ protein.

\section{$\left[{ }^{3} H\right]$ Thymidine incorporation assay}

EC were seeded on twenty-four multi-well plates (NUNC) at a density of $9 \times 10^{4}$ cells/well in DMEM supplemented with $10 \%$ FCS and were allowed to grow to $60-70 \%$ confluence. Cells were synchronised by placing in serum-free DMEM for $24 \mathrm{~h}$, and further exposed to $10 \mathrm{nM}$ Gen or vehicle control (ethanol $<0.1 \%$ ) for $24 \mathrm{~h}$ in fresh DMEM containing $1 \%$ FCS. The cells were pulsed with $37 \mathrm{~Bq} / \mathrm{ml}$ of $\left[{ }^{3} \mathrm{H}\right]$ thymidine during last $2 \mathrm{~h}$ of treatment. Cells were rinsed twice with PBS in order to remove the unincorporated $\left[{ }^{3} \mathrm{H}\right]$ thymidine. Ice-cold TCA $(10 \%)$ was added, and the acid-insoluble material was dissolved with $1 \mathrm{M} \mathrm{NaOH}$. Radioactivity was measured by liquid scintillation, and $\left[{ }^{3} \mathrm{H}\right]$ thymidine incorporation was normalised to protein content ${ }^{(18,23)}$.

\section{RT-PCR assay}

EC were treated with Gen, bacterial LPS $(1 \mu \mathrm{g} / \mathrm{ml})$ or Gen plus bacterial LPS (the isoflavone was added $5 \mathrm{~h}$ before bacterial LPS addition). Respective control with vehicle alone (ethanol $0.1 \%$ ) was also processed. Total cellular RNA extraction and reverse transcription were performed using Superscript III CellsDirect cDNA synthesis system according to the manufacturer's instructions. Complementary DNA was then amplified by PCR using a programmed thermocycler (Biometra Uno II; Biometra, Göttingen, Germany). PCR cycles were as follows: E-selectin $\left(95^{\circ} \mathrm{C}, 3 \mathrm{~min}, 94^{\circ} \mathrm{C}\right.$, $30 \mathrm{~s}, 53^{\circ} \mathrm{C}, 45 \mathrm{~s}, 72^{\circ} \mathrm{C}, 60 \mathrm{~s}, 72^{\circ} \mathrm{C}, 7 \mathrm{~min}, 32$ cycles); P-selectin $\left(94^{\circ} \mathrm{C}, 3 \mathrm{~min}, 94^{\circ} \mathrm{C}, 30 \mathrm{~s}, 62^{\circ} \mathrm{C}, 45 \mathrm{~s}, 72^{\circ} \mathrm{C}, 45 \mathrm{~s}, 72^{\circ} \mathrm{C}, 7 \mathrm{~min}\right.$, 38 cycles); VCAM- $1\left(95^{\circ} \mathrm{C}, 3 \mathrm{~min}, 95^{\circ} \mathrm{C}, 60 \mathrm{~s}, 55^{\circ} \mathrm{C}, 60 \mathrm{~s}\right.$, $72^{\circ} \mathrm{C}, 60 \mathrm{~s}, 72^{\circ} \mathrm{C}, 7 \mathrm{~min}, 32$ cycles $)$. Primers sequences were as follows ${ }^{(24,25)}$ : E-selectin, forward: $5^{\prime}$ CAA CGT GCA CGT TTG ACT GT $3^{\prime}$, reverse: $5^{\prime}$ AGG TCA AGG CTT GAA CAC TG 3'; P-selectin, forward: 5' TAA TCC CCC GCA GTG TAA AG 3', reverse: 5' AGG TTG GCA ATG GTT CAC TC 3'; VCAM-1, forward: 5' TAA GTT ACA CAG CAG TCA AAT GGA $3^{\prime}$. The expression of housekeeping gene glyceraldehyde-3-phosphate dehydrogenase was checked for each set of RT-PCR experiments 
(forward primer: $5^{\prime}$ TCC CTC AAG ATT GTC AGC AA 3', reverse primer: $5^{\prime} \mathrm{AGA}$ TCC ACA ACG GAT ACA TT $3^{\prime}$; amplification steps: $95^{\circ} \mathrm{C}, 3 \mathrm{~min}, 94^{\circ} \mathrm{C}, 30 \mathrm{~s}, 53^{\circ} \mathrm{C}, 30 \mathrm{~s}$, $72^{\circ} \mathrm{C}, 45 \mathrm{~s}, 72^{\circ} \mathrm{C}, 7 \mathrm{~min}, 35$ cycles). Negative controls were also processed. PCR amplification products were detected by electrophoresis in agarose gels stained with ethidium bromide. Results were obtained from at least four independent experiments.

\section{DNA fragmentation assay}

EC cultured in DMEM containing 1\% FCS were exposed to Gen or vehicle alone. $\mathrm{H}_{2} \mathrm{O}_{2}(200 \mu \mathrm{M})$ was employed as apoptosis inducer. In Gen plus $\mathrm{H}_{2} \mathrm{O}_{2}$ treatment, Gen was added at the beginning and $\mathrm{H}_{2} \mathrm{O}_{2}$ addition was made in the last $6 \mathrm{~h}$ of the treatment. Cells were washed twice with PBS and lysated with $10 \mathrm{~mm}$ EDTA, $400 \mathrm{~mm} \mathrm{NaCl}, 1 \mathrm{mg} / \mathrm{ml}$ proteinase $\mathrm{K}$, $35 \mathrm{~mm}$ SDS and $10 \mathrm{~mm}$ Tris $-\mathrm{HCl} \mathrm{pH} 8.2$ at $37^{\circ} \mathrm{C}$ overnight. DNA was extracted using phenol-chloroform-isoamyl alcohol (25:24:1). DNA samples were separated by electrophoresis on $1 \%(\mathrm{w} / \mathrm{v})$ agarose gel containing $1 \mathrm{mg} / \mathrm{ml}$ of ethidium bromide and photographed on an ultraviolet transilluminator ${ }^{(26)}$. Integrity density was measured employing the image processing and analysis software of the NIH, ImageJ, $1.43 \mathrm{c}$ version $^{(27)}$.

\section{Cells adhesion assay}

Peripheral blood mononuclear cell and monocyte isolation. Separation of peripheral blood mononuclear cell was performed by density gradient ${ }^{(28)}$. Heparinised whole blood diluted with PBS (1:1) was carefully layered onto FicollPaque Plus and centrifuged at $400 \mathrm{~g}$. Mixed mononuclear cell interface was collected, and viability was checked with trypan blue. Peripheral blood mononuclear cell were suspended in DMEM-10\% FCS and placed on NUNC Petri dishes $\left(2.0 \times 10^{7}\right.$ cells $\left./ \mathrm{ml}\right)$ for $1 \mathrm{~h}$ at $37^{\circ} \mathrm{C}$ to allow peripheral blood monocyte (PBM) adhesion. Monocytes morphology was determined by May-Grünwald-Giemsa staining. The culture medium containing non-adherent cells was removed. Adhered cells were incubated for $15 \mathrm{~min}$ in PBS-EDTA $10 \mathrm{~mm}$, washed and cultured in DMEM-10\% FCS, $60 \mu \mathrm{g} / \mathrm{ml}$ penicillin, $100 \mu \mathrm{g} / \mathrm{ml}$ streptomycin for $72 \mathrm{~h}$. Medium was replaced at $48 \mathrm{~h}$. Adherent cells were detached using a rubber policeman and suspended in DMEM. Absolute number of PBM was counted using an automatised counter. Viability was newly confirmed with trypan blue assay.

Peripheral blood monocyte adhesion assay. EC were starved for $24 \mathrm{~h}$ with serum-free medium, and then exposed to Gen, LPS or Gen plus bacterial LPS in DMEM (1\% FCS) as indicated in each experiment. An exact number of PBM were seeded on pretreated EC and incubated for $2 \mathrm{~h}$ at $37^{\circ} \mathrm{C}$ in a humidified $5 \% \mathrm{CO}_{2}$ atmosphere ${ }^{(29)}$. Supernatants of each well containing non-adhered PBM were collected and counted. The number of adhered PBM to EC was calculated by the difference between total mononuclear seeded and non-adherent PBM. EC and adhered PBM were dyed using Giemsa stain. Images $(\times 200)$ were obtained using an OLYMPUS C7070WZ optical microscope system. Results are expressed as means and standard deviations of number of cells counted.

\section{Endothelial cell migration assay}

EC were seeded at a density of $5 \times 10^{5}$ cells $/ \mathrm{cm}^{2}$ in $60 \mathrm{~mm}$ NUNC dishes with DMEM containing $10 \%$ FCS, and were grown to $90 \%$ confluence. Cells were starved for $24 \mathrm{~h}$ with serum-free medium. In order to evaluate EC migration, two scratch wound assays were carried out within the same well in each condition: (a) a strip was scratched using a $200 \mu \mathrm{l}$ pipette tip ${ }^{(30)}$; (b) a wound was made by pressing a razor blade down on the dish to cut the cell layer. The blade was then gently moved to one side to remove part of the monolayer. Immediately after that, the adhered cells were washed twice with PBS and cultured in fresh DMEM containing $1 \%$ FCS plus Gen or vehicle control. After $48 \mathrm{~h}$ of culture, cells were fixed in glutaraldehyde $0.1 \%$ and stained with haematoxylineosin. Migration was quantified by counting the number of cell nuclei that migrated at scratched area in at least seven different microscopic fields representative of each culture plate. EC migration was recorded using an OLYMPUS C7070WZ optical microscope system. Results are expressed as means and standard deviations of number of migrated cells/field ${ }^{(31,32)}$.

\section{Statistical analysis}

Each experimental condition has been performed in three independent experiments performed by quadruplicate. All data are presented as means and standard deviations. Comparisons between two means were made using Student's $t$ test, and multiple comparisons were made with ANOVA using SSPS Statistical software version 10.0 for Windows. Differences of $P<0.05$ were considered significant.

\section{Results}

In order to evaluate the effect of Gen on EC proliferation, we employed the $\left[{ }^{3} \mathrm{H}\right]$ thymidine incorporation technique. Figure 1

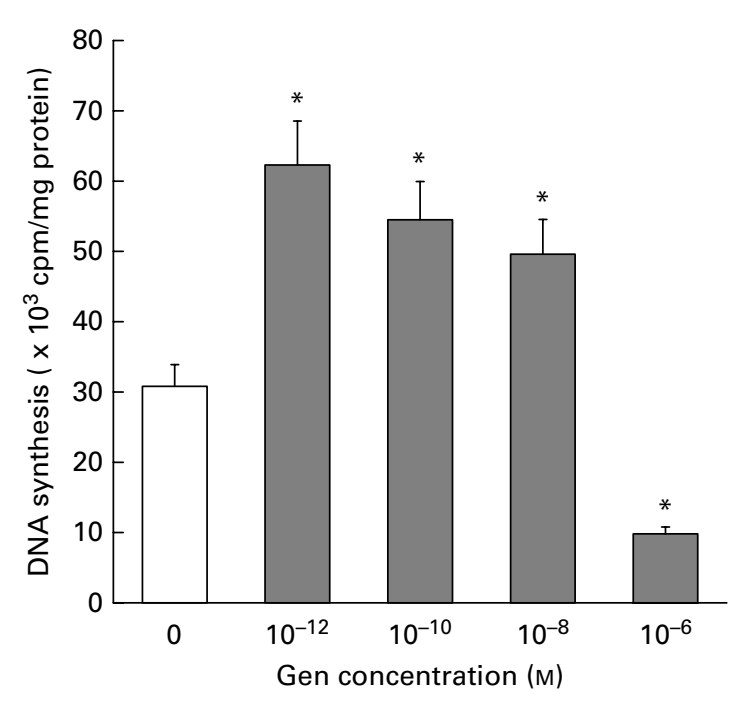

Fig. 1. Effect of genistein (Gen) on endothelial cells (EC) proliferation. Starved EC cultures were incubated with different concentrations of Gen for 24h. $\left[{ }^{3} \mathrm{H}\right]$ Thymidine incorporation was measured as described in the Materials and methods section. Results represent the means and standard deviations of three independent experiments $(n 4)$. ${ }^{*}$ Mean values were significantly different $(P<0.001)$ with respect to control value. 
shows that Gen significantly increased cell proliferation after $24 \mathrm{~h}$ of treatment. This mitogenic effect was seen in a wide range of submicromolar concentration, $0 \cdot 001-10 \mathrm{nM},(30 \cdot 80$ $(\mathrm{SD} 2.46)$ v. 62.3 (SD 6.67); 54.5 (SD 6.20); 49.6 (SD $\left.4.47 \times 10^{3}\right) \mathrm{cpm} / \mathrm{mg}$ protein, control $v$. Gen $10^{-12}, 10^{-10}$ and $10^{-8} \mathrm{M}$, respectively, $\left.P<0 \cdot 001\right)$. At higher concentration $(1 \mu \mathrm{M})$, the phyto-oestrogen significantly inhibited EC proliferation $\left(30.8(\mathrm{SD} 2.46) v .9 .8(\mathrm{SD} 2.21) \times 10^{3} \mathrm{cpm} / \mathrm{mg}\right.$ protein, control $v$. Gen $\left.10^{-6} \mathrm{M}, P<0 \cdot 001\right)$. No significant differences in DNA synthesis were observed after $48 \mathrm{~h}$ of treatment (not shown). To test whether ER would mediate the proliferative action of Gen, EC were preincubated with the high affinity ER antagonist ICI 182780 for $30 \mathrm{~min}$ before phyto-oestrogen treatment. As can be observed in Table 1, the presence of ER antagonist completely suppressed the proliferative effect elicited by Gen.

It is widely known that NO is an important second messenger of the endothelium. We have previously reported that, in rat aortic strips, Gen stimulates NO production through a non-genomic mechanism of action. Since endothelial and smooth muscle cells coexist in aortic rings, we evaluated if the phyto-oestrogen enhances NO synthesis at endothelial level. NO was measured after rapid stimulation of EC with the isoflavone (Fig. 2). The phyto-oestrogen treatment significantly increased NO production between 5 and $30 \mathrm{~min}$ (50, 61, 80, 139 and $48 \%$ above each control value) with similar kinetic profile as the control group, exhibiting maximal stimulation at $20 \mathrm{~min}$. The stimulatory action of Gen on NO synthesis was time dependent, since statistical differences were detected among each treatment times.

We tested the hypothesis whether NO pathway participates in the regulation of EC proliferation induced by Gen. To that end, we selected the compound L-nitro-arginine methyl ester as specific NOS inhibitor and measured DNA synthesis in the presence of this compound. Table 1 shows that the preincubation with L-nitro-arginine methyl ester suppressed the proliferative effect elicited by $24 \mathrm{~h}$ treatment with $10 \mathrm{~nm}$ Gen. Taken together, the results of Fig. 2 and Table 1 suggest that the mitogenic action of the isoflavone involves the participation of ER and NOS pathway.

The effect of Gen on PBM adhesion to EC was measured using cell adhesion assay. Cells were treated with $10 \mathrm{nM}$ Gen for different time intervals, and immediately after

Table 1. Effect of L-nitro-arginine methyl ester (L-NAME) and $\mathrm{ICl}$ 182780 on mitogenic action of genistein (Gen)†

(Mean values and standard deviations of three independent experiments $(n 4))$

\begin{tabular}{llllll}
\hline & \multicolumn{3}{c}{ DNA synthesis $\left(\times 10^{3} \mathrm{cpm} / \mathrm{mg}\right.$ protein $)$} \\
\cline { 2 - 3 } \cline { 6 - 7 } & \multicolumn{2}{c}{ Control } & & \multicolumn{2}{c}{$10 \mathrm{nM}$ Gen } \\
\cline { 2 - 3 } \cline { 5 - 6 } & Mean & SD & & Mean & SD \\
\hline ICI 182780 & 30.84 & 2.46 & & $49.65^{\star}$ & 4.47 \\
+ L-NAME & 28.20 & 2.26 & & 30.11 & 3.09 \\
\hline
\end{tabular}

* Mean value was significantly different from that for the vehicle treatment $(P<0.001)$.

†EC cultures were preincubated with L-NAME $(10 \mu \mathrm{M})$ or ICI $182780(1 \mu \mathrm{M})$ for $1 \mathrm{~h}$, and immediately after that exposed to $10 \mathrm{~nm}$ Gen for $24 \mathrm{~h} .\left[{ }^{3} \mathrm{H}\right]$ thymidine incorporation was measured as described in the Materials and methods section.

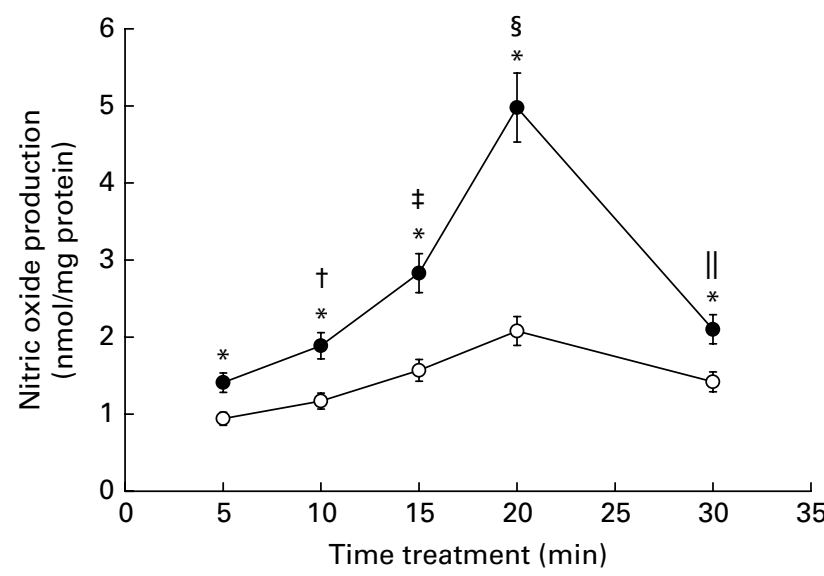

Fig. 2. Effect of genistein (Gen) on nitric oxide production: time-response profile. Starved endothelial cells were treated with $10 \mathrm{~nm}$ Gen at the indicated times. Nitric oxide production was measured by Griess reaction as described in the Materials and methods section. Results represent the means and standard deviations of three independent experiments $(n 4)$. Mean values were significantly different: ${ }^{\star} P<0.001$ with respect to each control value; $\dagger P<0.001 v$. Gen $5 \mathrm{~min} ; \ddagger P<0.001 \mathrm{v}$. Gen $10 \mathrm{~min} ; \S P<0.001 \mathrm{v}$. Gen $15 \mathrm{~min} ; \| P<0.001$ v. Gen $20 \mathrm{~min}$. ๑, $10 \mathrm{~nm}$ Gen; $\bigcirc$, control.

that isolated PBM were added. Table 2 shows that isoflavone treatment exhibited lesser monocyte adhesion with respect to the control group. This inhibitory effect was seen after $13-46 \mathrm{~h}$ of exposure to the phyto-oestrogen. When EC were exposed to bacterial LPS $(1 \mu \mathrm{g} / \mathrm{ml})$, enhancement of PBM adhesion was observed (Fig. 3 and Table 3 ). This adhesion was partially attenuated when EC were pretreated with $10 \mathrm{nM}$ Gen for $24 \mathrm{~h}$ before bacterial LPS addition (988 (SD 98) v. 1430 (SD 165) cells/ $\mu 1$, Gen + LPS $v$. Control + LPS). The results from Table 2 and Fig. 3 suggest that Gen treatment not only inhibited leucocyte adhesion in a free proinflammatory agent's microenvironment but also attenuated bacterial LPS-induced monocyte adhesion.

Taking in account these observations, we focused our attention on cell adhesion-related genes. Employing RT-PCR technique, we evaluated the Gen regulation on cell mRNA expression of E-selectin, VCAM-1 and P-selectin adhesion

Table 2. Effect of genistein (Gen) on peripheral blood monocyte (PBM) endothelial cells (EC) adhesion at different times of treatment $†$

(Mean values and standard deviations of three independent experiments $(n 4))$

\begin{tabular}{|c|c|c|}
\hline & \multicolumn{2}{|c|}{$\begin{array}{l}\text { Number of adhered monocytes to } \\
\qquad \mathrm{EC}(\text { cells } / \mu \mathrm{l})\end{array}$} \\
\hline & Mean & SD \\
\hline Control & $1014 \cdot 0$ & $108 \cdot 0$ \\
\hline $10 \mathrm{~nm}$ Gen $13 \mathrm{~h}$ & $710 \cdot 0^{\star \star *}$ & $88 \cdot 0$ \\
\hline Control & $986 \cdot 0$ & $101 \cdot 0$ \\
\hline $10 \mathrm{~nm}$ Gen $21 \mathrm{~h}$ & $769 \cdot 0^{\star \star}$ & $97 \cdot 0$ \\
\hline Control & $1040 \cdot 0$ & $108 \cdot 0$ \\
\hline $10 \mathrm{~nm}$ Gen $46 \mathrm{~h}$ & $864 \cdot 0^{*}$ & $94 \cdot 0$ \\
\hline
\end{tabular}

Mean values compared with respective control value: ${ }^{*} P<0.05$, ${ }^{\star *} P<0.01$, *** $P<0.001$.

†EC cultures were treated with $10 \mathrm{~nm}$ Gen for 13,21 and $46 \mathrm{~h}$. Subsequently, PBM were seeded on the monolayer and incubated for $2 \mathrm{~h}$. Supernatant containing non-adhered PBM was removed, and non-adhered cells were counted. 

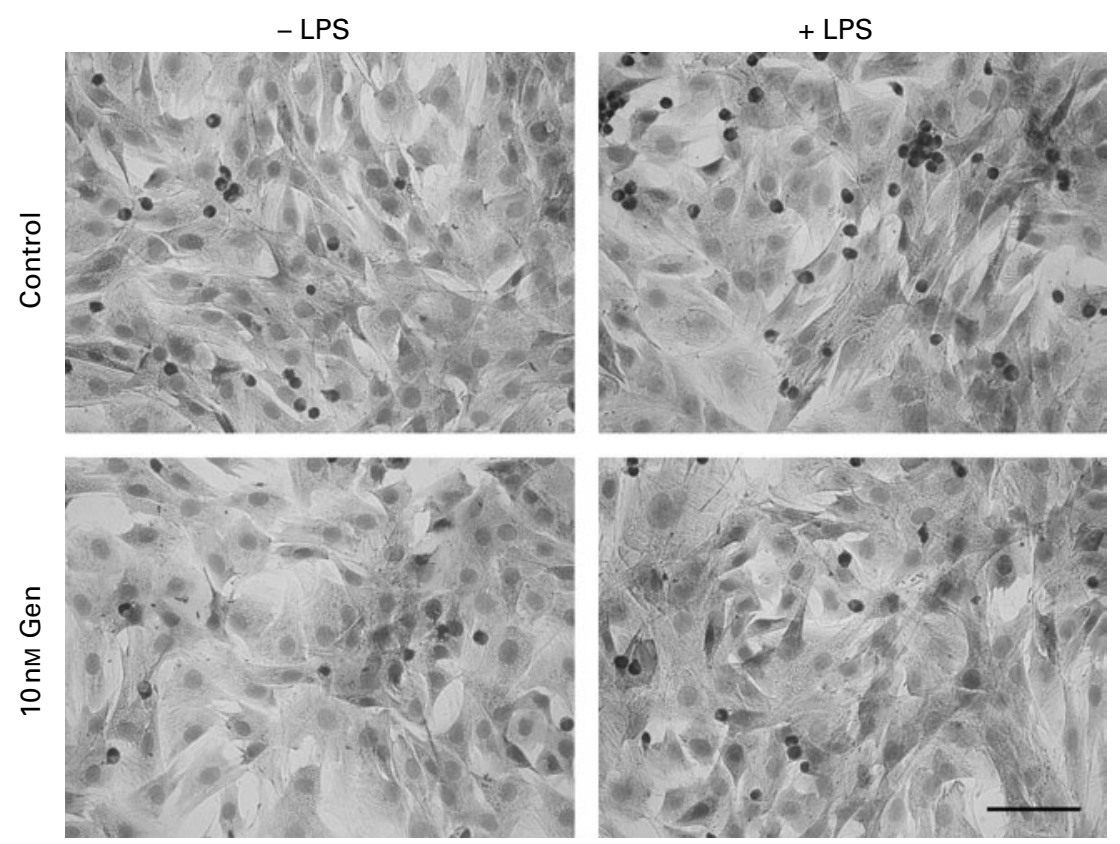

Fig. 3. Effect of genistein (Gen) on monocyte/macrophage endothelial cell (EC) adhesion. EC cultures were treated with $10 \mathrm{~nm}$ Gen for $46 \mathrm{~h}$ in the presence or absence of $1 \mu \mathrm{g} / \mathrm{ml}$ lipopolysaccharide (LPS), which was added $24 \mathrm{~h}$ after Gen treatment. Peripheral blood monocyte (PBM) were seeded to cell monolayer for $2 \mathrm{~h}$, and immediately after that the supernatant was removed and the non-adhered PBM were counted. Images show representative fields of each experimental condition $(\times 200)$. The scale bar represents $70 \mu \mathrm{m}$.

molecules. To that end, EC were exposed to the phyto-oestrogen in the presence or absence of LPS. As can be observed in Fig. 4, the mRNA levels of all molecules were marked enhanced after $20 \mathrm{~h}$ treatment with bacterial LPS (line D). Gen $(10 \mathrm{~nm})$ added alone (line A) down-regulated the mRNA expression of E-selectin, VCAM-1 and P-selectin. Moreover, when Gen was added before bacterial LPS treatment (line B), a partial (P-selectin) or complete (VCAM-1, E-selectin) downregulation of the enhancement of mRNA expression induced by bacterial LPS was detected.

Since DNA fragmentation is a key feature of cell undergoing apoptosis, we used electrophoretic analysis of DNA to evaluate the role of Gen on EC programmed death. EC were incubated for $24 \mathrm{~h}$ with $10 \mathrm{nM}$ Gen. $\mathrm{H}_{2} \mathrm{O}_{2}(200 \mu \mathrm{M})$ was employed as apoptosis inductor. Fig. 5 shows an image of a representative ladder pattern of internucleosomal fragmentation (left) and the quantification of unfragmented DNA (right). Under basal conditions (without $\mathrm{H}_{2} \mathrm{O}_{2}$ ), DNA extracted from control and Gen-treated cells remain unfragmented. $\mathrm{H}_{2} \mathrm{O}_{2}$ addition induced a markedly DNA laddering compared with control cells. Preincubation with Gen before $\mathrm{H}_{2} \mathrm{O}_{2}$ addition, partially reverses DNA fragmentation elicited by the apoptotic inductor $(94 v .34 \%$ DNA fragmentation, $\mathrm{H}_{2} \mathrm{O}_{2}$ v. $\mathrm{H}_{2} \mathrm{O}_{2}+\mathrm{Gen}$, respectively). These results suggest that the phyto-oestrogen attenuated the induction of apoptosis evoked by oxidative stress.

Since cell migration is an important physiological process implicated in vascular tissue healing and reendothelialisation, we investigate the effect of Gen on EC migration. Figure 6 (a) and (b) shows representative microphotography of cell migration assays ( 0 and $48 \mathrm{~h}$ after scraping). The figure shows that the cells have passed the demarcated line and migrated to denuded area after $48 \mathrm{~h}$ of treatment with Gen or vehicle alone. As can be seen in Fig. 6(c), a minor number of cells crossed the demarcated line in Gen-treated culture in comparison to control condition (170 (SD 18) v. 65 (SD 6) number of cells/field, control v. $10 \mathrm{~nm}$ Gen), suggesting that Gen inhibits EC migration.

\section{Discussion}

The present study shows that the isoflavone Gen would exert a protective effect on vascular endothelium, due to its regulatory action on EC proliferation, apoptosis and leucocyte adhesion, events that play a critical role in vascular diseases. This modulatory action was detected either under physiological or inflammatory conditions. The molecular mechanism displayed by the phyto-oestrogen involves the participation of ER and the activation of NO pathway.

Table 3. Effect of genistein (Gen) on peripheral blood monocyte (PBM) endothelial cells (EC) adhesion\|

(Mean values and standard deviations of three independent experiments ( $n$ 4))

\begin{tabular}{|c|c|c|}
\hline & \multicolumn{2}{|c|}{$\begin{array}{l}\text { Number of adhered monocytes to } \\
\qquad \mathrm{EC}(\text { cells } / \mu \mathrm{l})\end{array}$} \\
\hline & Mean & SD \\
\hline Control - LPS & $1009 \cdot 0$ & $102 \cdot 0$ \\
\hline Control + LPS & $1430 \cdot 0^{*}$ & $165 \cdot 0$ \\
\hline $10 \mathrm{~nm}$ Gen - LPS & $786.0 \dagger$ & 90.0 \\
\hline $10 \mathrm{~nm}$ Gen + LPS & $988.0 \pm \S$ & $98 \cdot 0$ \\
\hline
\end{tabular}

Mean values were significantly different: ${ }^{*} P<0.01 \mathrm{v}$. control, $\dagger P<0.01 \mathrm{v}$. controlLPS, $\ddagger P<0.01 v$. Gen, $\S P<0.01 v$. control + LPS.

$\| E C$ cultures were treated with $10 \mathrm{~nm}$ Gen for $46 \mathrm{~h}$ in the presence or absence of $1 \mu \mathrm{g} / \mathrm{ml}$ LPS, which was added $24 \mathrm{~h}$ after Gen treatment. PBM were seeded to the cell monolayer for $2 \mathrm{~h}$, and immediately after that the supernatant was removed and the non-adhered PBM were counted. 


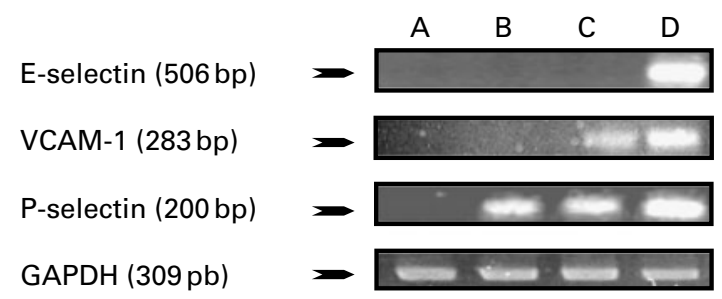

Fig. 4. Expression of endothelial cell (EC) adhesion molecules mRNA: regulation by genistein (Gen). EC were incubated with $10 \mathrm{~nm}$ Gen for $25 \mathrm{~h}$ (lane A), $10 \mathrm{~nm}$ Gen $5 \mathrm{~h}+$ bacterial lipopolysaccharide (LPS) for $20 \mathrm{~h}$ (lane B), vehicle alone (lane C) or $1 \mu \mathrm{g} / \mathrm{ml}$ bacterial LPS for $20 \mathrm{~h}$ (lane D). RT-PCR was performed as described in the Materials and methods section. PCR amplification products of E-selectin, VCAM-1, P-selectin are shown. The expected bands sizes are indicated. Results represent the means and standard deviations of three independent experiments ( $n$ 4). VCAM-1, vascular cell adhesion molecule; GAPDH, glycerldehyde-3-phosphate dehydrogenase.

Serum concentration of Gen in human consuming dietary soya supplementation varies between $0.74-2.5 \mu \mathrm{M}$ in $A \operatorname{sian}^{(33)}$ and $14-20 \mathrm{~nm}$ in western population ${ }^{(34)}$. The concentration of Gen employed in the present study $(0 \cdot 1-$ $100 \mathrm{nM})$ is close to these human plasma circulating levels.

We demonstrated that low concentration of Gen stimulated EC proliferation. At high doses, similarly as reported by other authors $^{(35,36)}$, Gen exhibited an anti-mitogenic effect. Gen exerts both oestrogenic and non-oestrogenic actions that depend on the isoflavone concentration. It is described that Gen acts as protein tyrosine kinase inhibitor at concentrations higher than $10 \mu \mathrm{M}$, meanwhile at lower concentration, Gen binds to both isoforms of ER, having high affinity for ER- $\beta$. Moreover, it has been reported that, in human umbilical EC, $100 \mathrm{nM}$ Gen strikingly increases ER- $\beta$ expression ${ }^{(37)}$. We provided evidence that the mechanism of action of Gen involves ER participation, since the ER antagonist ICI 182780 blocked the mitogenic effect of the isoflavone. In agreement with this observation, we have previously reported the involvement of ER in the non-genomic stimulation of vasoactive compounds synthesis induced by Gen.

Endothelial-derived NO is a critical molecule for normal function of vessel, as well as for the progression/reversal of vascular disease. NO represents an important intracellular second messenger with potent vasodilator, anti-inflammatory, anti-atherogenic, anti-thrombotic and anti-apoptotic properties ${ }^{(38)}$. We have previously demonstrated that, in rat aortic rings, Gen acutely stimulates NO synthesis in a non-genomic manner ${ }^{(17)}$. In the present study, using isolated EC, we confirmed that this stimulatory action was exerted at endothelial level. The kinetic profile exhibited by Gen has a maximal stimulation of NO production at $20 \mathrm{~min}$. This observation is in accordance with other authors ${ }^{(15)}$ who have showed that in bovine and human EC, Gen $(1-10 \mu \mathrm{M})$ rapidly activates eNOS with maximal effect between 10 and $30 \mathrm{~min}$. It has been reported that Gen stimulates NOS in a protein kinase A-dependent manner ${ }^{(15)}$. Other studies showed that ER modulators non-genomically enhance NOS activity through sequential activation of mitogen-activated protein kinase and phosphatidylinositol-3-kinase/Akt pathways ${ }^{(39)}$. Indeed, the natural oestrogen $17-\beta$-oestradiol stimulates NO synthesis via $\mathrm{ER} / \mathrm{mitogen}$-activated protein kinase and phosphatidylinositol-3-kinase activation ${ }^{(40)}$. Since we proposed that in our experimental model, the effect of Gen on NO production is mediated by ER, some of these intracellular signal transduction pathways may be involved in Gen action. This fact will be the subject of future studies.

We obtained evidence that shows a cross-talk between genomic and non-genomic effects of the isoflavone. When NO synthesis was suppressed by the presence of the NOS inhibitor L-nitro-arginine methyl ester, the mitogenic action of Gen was abolished. It has been reported that NO mediates the stimulation of EC proliferation and migration induced by IL-33, a member of the IL-1 cytokine family ${ }^{(41)}$. Some of the mechanisms proposed to be implicated in NO-mediated stimulation of cell proliferation are as follows: (a) the rapid release of NO activates the cytosolic guanylyl cyclase/PKG system which phosphorylates Raf-1 kinase and activates mitogen-activated protein kinase pathway; (b) up-regulation of cyclo-oxygenase-2 via phosphatidylinositol-3-kinase/Akt in a NO-dependent manner; (c) activation of cell cycle machinery enhancing expression of cyclin or decreasing cyclin-dependent kinase inhibitors ${ }^{(42)}$.

We showed that Gen reduces EC migration. This inhibitory effect would be relevant to avoid vascular endothelial denudation and to maintain its selective permeable barrier properties by providing a continuous non-thrombogenic lining for the vascular system or for exerting a protective effect against atherosclerosis lesion progression. EC migration in vivo is a complex mechanism regulated by the local balance between pro and inhibitors migratory factors, and the cellular movement depends on coordinating and sensing of cell surroundings ${ }^{(43)}$. Since, in our work we measured EC migration using isolated cells under static conditions, at present we could not address the potentially beneficial or deleterious effect of Gen on EC motility.

EC activation by proinflammatory cytokines or bacterial endotoxins predisposes to leucocyte recruitment. Monocytes adhesion is the first critical step in a vascular lesion.
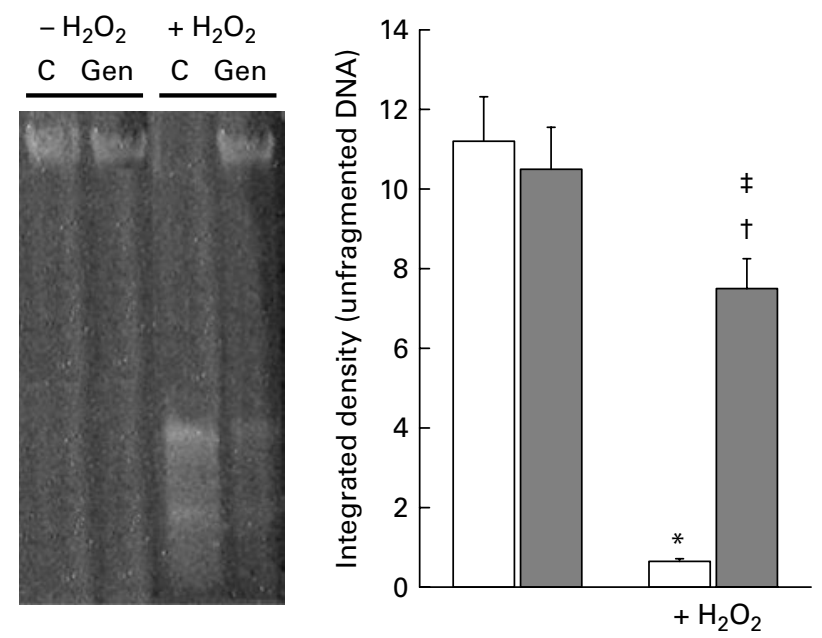

Fig. 5. Effect of genistein (Gen) on DNA fragmentation. Endothelial cell were incubated with $10 \mathrm{~nm}$ Gen or vehicle (C) for $24 \mathrm{~h}$ in the presence or absence of $200 \mu \mathrm{M} \mathrm{H} \mathrm{H}_{2} \mathrm{O}_{2}$ added $18 \mathrm{~h}$ after Gen treatment. DNA fragmentation was detected as described in the Materials and methods section. A representative image and results of integrated density of unfragmented DNA from three independent experiments are shown. ${ }^{\star} P<0.001 \mathrm{v}$. control; $\dagger P<0.01 \mathrm{v}$. $\mathrm{H}_{2} \mathrm{O}_{2} ; \ddagger P<0.01$ v. Gen. $\square, 10 \mathrm{~nm}$ Gen; $\square$, control. 

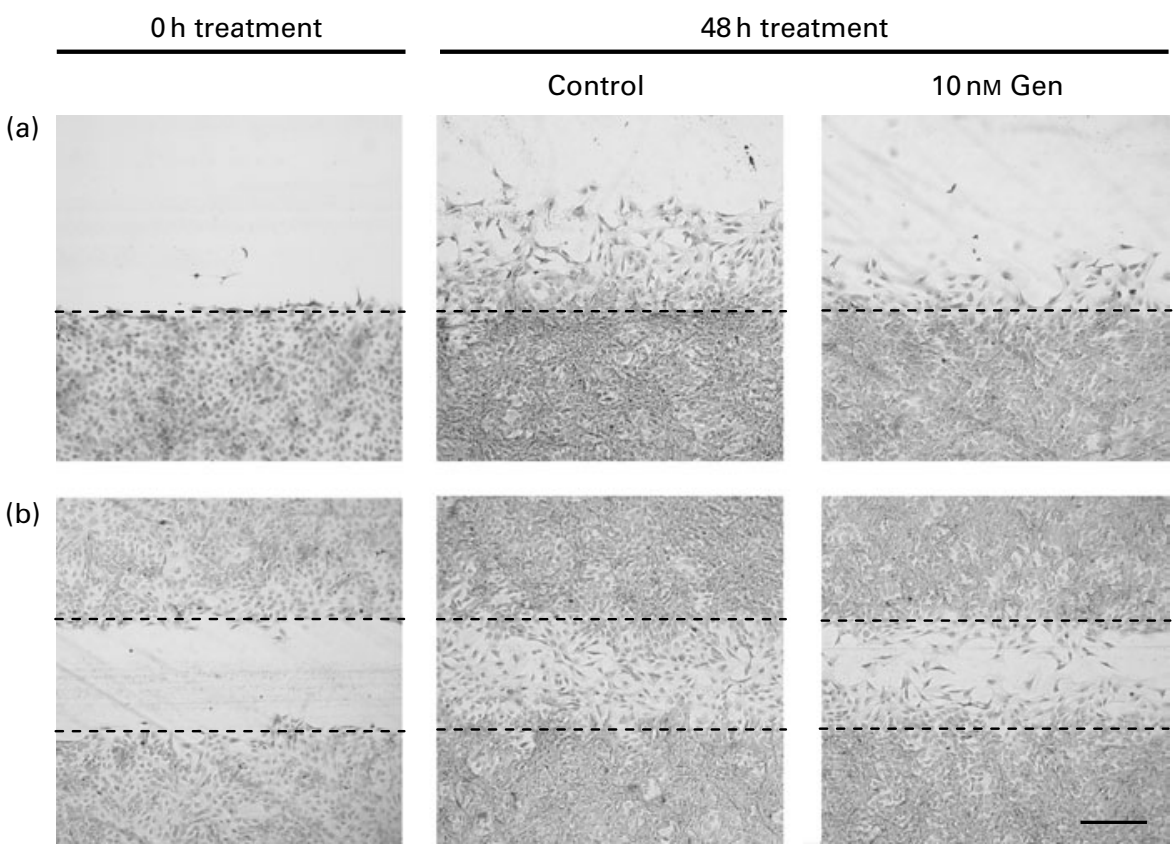

(c)

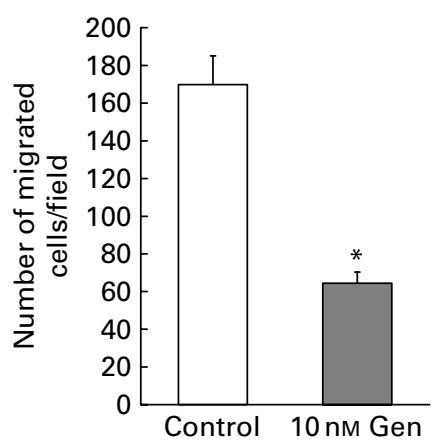

Fig. 6. Effect of genistein (Gen) on endothelial cells (EC) migration. Confluent EC cultures were serum starved for $24 \mathrm{~h}$, and cells were removed by scraping. Detached cells were washed with PBS, and the remaining monolayer was treated during $48 \mathrm{~h}$ with $10 \mathrm{~nm}$ Gen or vehicle. EC migration was recorded at 0 and $48 \mathrm{~h}$ after treatment. Dotted lines indicate the boundary between the unscratched and scratched areas. (a) and (b): Images of representative fields of each condition after haematoxylin-eosin staining $(\times 40)$. The scale bar represents $350 \mu \mathrm{m}$. (c) Bars show the means and standard deviations of number of migrated cells/field from three separated experiments performed by quadruplicate. ${ }^{*} P<0.001$.

EC injury induces synthesis or release of surface adhesion molecules. Since selectins (E and $\mathrm{P})$ are involved in initial leucocyte attachment and rolling, meanwhile, VCAM-1 triggers monocyte adherence and transendothelial migration to the intima ${ }^{(4)}$, we choose these CAM as target molecules to study. It has been reported that P- and E-selectins have overlapping and unique functions. P-selectin appears to be able for early leucocyte rolling and initial stages of an inflammatory response, while E-selectin allows slow and stable rolling and more leucocyte adhesion ${ }^{(44)}$. P-selectin stored within Weibel-Palade bodies may be recruited to the vessel surface as rapidly as few min after inflammatory mediators, reaching its peak after only $10 \mathrm{~min}$, followed by de novo synthesis of this selectin stimulated by the presence of proinflammatory agents such as bacterial LPS ${ }^{(45)}$. E-selectin is expressed constitutively on skin and bone microvessels, and it is induced by de novo synthesis in most organs and EC after inflammatory stimuli ${ }^{(46)}$. In the present study, we showed that Gen reduced monocyte adhesion to EC. Indeed, when
EC were exposed to a proinflammatory stimulus such as LPS, pretreatment with the isoflavone attenuated the enhancement in leucocyte adhesion induced by LPS. In RT-PCR assays, we demonstrated that, in EC incubated with the isoflavone before bacterial LPS stimulation, the mRNA levels of P-selectin, E-selectin and VCAM-1 were attenuated or blunted compared with bacterial LPS alone. The partial down-regulation of P-selectin observed in our experiments may be due to its kinetic/profile of expression. Pretreatment with Gen could attenuate the stimulation of P-selectin mRNA synthesis after its initial release from EC stores. Moreover, if a lesion is installed, P-selectin blunted synthesis could contribute to prevent its progression. The absence of E-selectin and VCAM-1 mRNA in Gen plus bacterial LPS treatment may be consistent with this proposal. These results may support the hypothesis that Gen treatment would have a protective effect on the endothelium by diminishing initial leucocyte adhesion but also preventing the progression of the lesion in a hostile environment. The activation of EC by 
bacterial LPS and cytokines conducts to the generation of intracellular reactive oxygen species (mostly hydrogen peroxide) and increases the transcription of adhesion molecules target genes via the NF-кB system ${ }^{(47)}$. Our results suggest that the inhibitory action of Gen on monocyte adhesion would be due to the regulation of EC adhesion molecules transcription. In agreement with this, in human umbilical vein endothelial cells, red clover extracts containing Gen and daidzein inhibit endothelial expression of ICAM-1 and VCAM-1 induced by bacterial LPS ${ }^{(48)}$. Moreover, down-regulation of mRNA levels of vascular endothelialcadherin, integrin $\alpha \mathrm{V}$ and multimerin by micromolar concentration of Gen has also been reported ${ }^{(49)}$. Of further interest is the fact that NO exerts a regulatory action on CAM expression. It has been demonstrated that NO inhibits both exocytosis and de novo synthesis of P-selectin ${ }^{(50,51)}$. Indeed, in human umbilical vein endothelial cells, Gen inhibits TNF $\alpha$-induced VCAM-1 expression in an NO-dependent manner ${ }^{(52)}$. Therefore, the non-genomic stimulatory action of Gen on NO production reported in our study would mediate the inhibitory action of the phyto-oestrogen on CAM expression by affecting either the initial or the later stage of monocyte adhesion. This hypothesis and the intracellular networks involved in Gen inhibitory action on monocytes adhesion will be further investigated in future studies.

EC lesion-prone regions are characterised by increased EC turnover rate, most likely due to enhance apoptosis. Classical risk factors such as oxidised LDL, oxidative stress and angiontensin II stimulate EC apoptosis ${ }^{(53-55)}$. The apoptotic cells are removed by the blood stream and are replaced by regenerated endothelium formed by neighbouring cells and/or circulating endothelial progenitor cells ${ }^{(56)}$. Our results show that Gen does not modify basal cell programme death rate, but under oxidative stress conditions, the isoflavone prevents $\mathrm{H}_{2} \mathrm{O}_{2}$-induced apoptosis. Gen inhibition of EC apoptosis via $\mathrm{Bcl}-2 / \mathrm{Bax}$ regulation in diabetic EC model has been reported ${ }^{(37)}$.

Taken together, the results obtained in monocytes adhesion assays and DNA laddering may support that Gen would exert a protective effect against oxidative stress or proinflammatory injury in vascular endothelium.

In summary, the present study provides an integral evaluation of the effect of Gen on cellular events that would be altered under vascular injury. The isoflavone might have a beneficial role on EC behaviour prompting vasoactives synthesis and reducing EC motility, apoptosis and monocyte adhesion, either under basal or injury conditions. Whether the administration of this phyto-oestrogen would be helpful to prevent, treat or reverse chronic inflammatory process that underlies many CVD remains to be clarified. Further investigations are required to understand the physiological relevance of our observations.

\section{Acknowledgements}

All the authors have seen and approved the contents of the submitted manuscript. All the authors stated that there are no conflicts of interest and all the authors adhere to the Committee on Publication Ethics guidelines on research and publication ethics. This research was supported by grants from the SGCyT, Universidad Nacional del Sur, Argentina (PGI 24/B093); Agencia Nacional de Promoción
Científica (PICTO 527, ANPCYT/UNS); Consejo Nacional de Investigaciones Científicas y Técnicas (PIP 5790 CONCET, Argentina). The contribution of each author was as follows: M. J. S., P. H. C. and M. B. R.: doing experiments; M. J. S., P. H. C., M. B. R. and V. L. M.: writing of the manuscript; V. L. M.: designing the study, promotor, investigator and coordinator.

\section{References}

1. De Caterina R (2000) Endothelial dysfunctions: common denominators in vascular disease. Curr Opin Lipidol 11, 9-23.

2. Ross R (1999) Atherosclerosis: an inflamatory disease. $N$ Engl J Med 340, 115-126.

3. Gimbrone MA Jr (1995) Vascular endothelium: an integrator of pathophysiologic stimuli in atherosclerosis. Am J Cardiol 75, 67B-70B.

4. Rao RM, Yang L, García-Cardena G, et al. (2007) Endothelialdependent mechanisms of leukocyte recruitment to the vascular wall. Circ Res 101, 234-247.

5. Mizia-Stec K (2006) Cytokines and adhesive molecules in detection of endothelial dysfunction. Pharmacol Rep 58, 21-32.

6. Choy JC, Granville DJ, Hunt DW, et al. (2001) Endothelial cell apoptosis: biochemical characteristics and potencial implications for atherosclerosis. J Mol Cell Cardiol 33, 1673-1690.

7. Burlacu A, Jinga V, Gafencu AV, et al. (2001) Severity of oxidative stress generates different mechanisms of endothelial cell death. Cell Tissue Res 306, 409-416.

8. Caulin-Glaser T, García-Cardena G, Sarrel P, et al. (1997) 17beta-estradiol regulation of human endothelial cell basal nitric oxide release, independent of cytosolic $\mathrm{Ca}^{2+}$ mobilization. Circ Res 81, 885-892.

9. Simoncini T, Maffei S, Basta G, et al. (2000) Estrogens and glucocorticoids inhibit endothelial vascular cell adhesion molecule-1 expression by different transcriptional mechanisms. Circ Res 87, 19-25.

10. Colacurci N, Chiàntera $\mathrm{A}$, Fornaro $\mathrm{F}$, et al. (2005) Effects of soy isoflavones on endothelial function in healthy postmenopausal women. Menopause 12, 299-307.

11. Reinli K \& Block G (1996) Phytoestrogen content of foods - a compedium of literature values. Nutr Cancer 26, 123-148.

12. Barnes S (1998) Phytoestrogens and breast cancer. Baillieres Clin Endocrinol Metab 12, 559-579.

13. Kuiper GG, Carlsson B, Grandien K, et al. (1997) Comparison of the ligand binding specificity and transcript tissue distribution of estrogen receptors alpha and beta. Endocrinology 138, 863-870.

14. Akiyama T, Ishida J, Nakagawa S, et al. (1987) Genistein, a specific inhibitor of tyrosine-specific protein kinases. J Biol Chem 262, 5592-5595.

15. Liu D, Homan L \& Dillon J (2004) Genistein acutely stimulates nitric oxide synthesis in vascular endothelial cells by a cyclic adenosine $5^{\prime \prime}$-monophosphate-dependent mechanism. Endocrinology 145, 5532-5539.

16. Dixon R \& Ferrerira D (2002) Genistein. Phytochemistry 60, 205-211.

17. Polini N, Rauschemberger MB, Mendiberri J, et al. (2007) Effect of genistein and raloxifene on vascular dependent platelet aggregation. Mol Cell Endocrinol 267, 55-62.

18. Cutini P, Sellés J \& Massheimer V (2009) Cross-talk between rapid and long term effect of progesterone on endothelial cells. J Steroid Biochem Mol Biol 115, 36-43.

19. Yeh YC, Hwang GY, Liu IP, et al. (2002) Identification and expression of scavenger receptor SR-BI in endothelial cells and smooth muscle cells of rat aorta in vitro and in vivo. Atherosclerosis 161, 95-103. 
20. Bachetti T \& Morbidelli L (2000) Endothelial cells in culture: a model for studying vascular functions. Pharmacol Res 42, 9-19.

21. Rauschemberger MB, Sellés J \& Massheimer V (2008) The direct action of estrone on vascular tissue involves genomic and non-genomic actions. Life Sci 82, 115-123.

22. Lowry OH, Rosebrough NJ, Farr AL, et al. (1951) Protein measurement with the Folin phenol reagent. J Biol Chem 193, 265-277.

23. Kyaw M, Yoshizumi M, Tsuchiya K, et al. (2002) Antioxidants inhibit endothelin-1 (1-31)-induced proliferation of vascular smooth muscle cells via the inhibition of mitogen-activated protein (MAP) kinase and activator protein-1 (AP-1). Biochem Pharmacol 64, 1521-1531.

24. Peng Lv, Shelley Chireyath P, Yanjv X, et al. (2006) Effects of thalidomide on the expression of adhesion molecules in rat liver cirrhosis. Mediators Inflamm 2006, 1-10.

25. Callera GE, Montezano AC, Touyz RM, et al. (2004) ETA receptor mediates altered leukocyte-endothelial cell interaction and adhesion molecules expression in DOCA-salt rats. Hypertension 43, 872-879.

26. Ohtsuka M, Miyashita Y \& Shirai K (2006) Lipids deposited in human atheromatous lesions induce apoptosis of human vascular smooth muscle cells. J Atheroscler Thromb 13, $256-262$.

27. Rasband W Image J 1.43 c Version - Image Processing and Analysis in Java. National Institutes of Health. Bethesda; available at http://rsb.info.nih.gov/ij/

28. Bøyum A (1968) Isolation of mononuclear cells and granulocytes from human blood. Scand J Clin Lab Invest 21 , Suppl. 97, 77-89.

29. Pawlowski NA, Abraham EL, Pontier S, et al. (1985) Human monocyte-endothelial cell interaction in vitro. Proc Natl Acad Sci U S A 82, 8208-8212.

30. Gojova A \& Barakat AI (2005) Vascular endothelial wound closure under shear stress: role of membrane fluidity and flow-sensitive ion channels. J Appl Physiol 98, 2355-2362.

31. Bürk RR (1973) A factor from a transformed cell line that affects cell migration. Proc Natl Acad Sci U S A 70, 368-372.

32. Pedram A, Razandi M, Aitkenhead M, et al. (2002) Integration of the non-genomic and genomic actions of estrogen. Membrane-initiated signaling by steroid to transcription and cell biology. J Biol Chem 277, 50768-50775.

33. Izumi T, Piskula MK, Osawa S, et al. (2000) Soy isoflavone aglycones are absorbed faster and in higher amounts than their glucosides in humans. J Nutr 130, 1695-1699.

34. Bhakta D, Higgins CD, Sevak L, et al. (2006) Phyto-oestrogen intake and plasma concentrations in South Asian and native British women resident in England. Br J Nutr 95, $1150-1158$.

35. Koroma BM \& de Juan E Jr (1994) Phosphotyrosine inhibition and control of vascular endothelial cell proliferation by genistein. Biochem Pharmacol 48, 809-818.

36. Fotsis T, Pepper M, Adlercreutz H, et al. (1993) Genistein, a dietary-derived inhibitor of in vitro angiogenesis. Proc Natl Acad Sci U S A 90, 2690-2694.

37. Xu SZ, Zhong W, Ghavideldarestani M, et al. (2009) Multiple mechanisms of soy isoflavones against oxidative stress-induced endothelium injury. Free Radic Biol Med 47, 167-175.
38. Moncada S (1997) Nitric oxide in the vaculature: physiology and pathophysiology. Ann N Y Acad Sci 811, 427-436.

39. Simoncini T, Varone G, Fornari L, et al. (2002) Genomic and nongenomic mechanisms of nitric oxide synthesis induction in human endothelial cells by a fourth-generation selective estrogen receptor modulator. Endocrinology 143, 2052-2061.

40. Meyer MR, Haas E, Prossnitz ER, et al. (2009) Non-genomic regulation of vascular cell function and growth by estrogen. Mol Cell Endocrinol 308, 9-16.

41. Choi YS, Choi HJ, Min JK, et al. (2009) Interleukin-33 induces angiogenesis and vascular permeability through ST2/TRAF6mediated endothelial NO production. Blood 114, 3117-3126.

42. Villalobo A (2007) Enhanced cell proliferation induced by nitric oxide. Dyn Cell Biol 1, 60-64.

43. Lamalice L, Le Boeuf F \& Huot J (2007) Endothelial cell migration during angiogenesis. Circ Res 100, 782-794.

44. Jung U \& Ley K (1999) Mice lacking two or all three selectins demonstrate overlapping and distinct functions for each selectin. J Immunol 162, 6755-6762.

45. Blann AD, Nadar SK \& Lip GYH (2003) The adhesion molecule P-selectin and cardiovascular disease. Eur Heart $J$ 24, 2166-2179.

46. Barthel SR, Gavino JD, Descheny L, et al. (2007) Targeting selectins and selectin ligands in inflammation and cancer. Expert Opin Ther Targets 11, 1473-1491.

47. Collins T, Read M, Neish AS, et al. (1995) Transcriptional regulation of endothelial cell adhesion molecules: NF-kappa B and cytokine-inducible enhancers. FASEB $J$ 9, 899-909.

48. Simoncini T, Garibaldi S, Fu XD, et al. (2008) Effects of phytoestrogens derived from red clover on atherogenic adhesion molecules in human endothelial cells. Menopause 15, 542-550.

49. Piao M, Mori D, Satoh T, et al. (2006) Inhibition of endothelial cell proliferation, in vitro angiogenesis, and the down-regulation of cell adhesion-related genes by genistein. Combined with a cDNA microarray analysis. Endothelium 13, 249-266.

50. Armstead VE, Minchenko AG, Schuhl RA, et al. (1997) Regulation of P-selectin expression in human endothelial cells by nitric oxide. Am $J$ Physiol Herat Circ Physiol 273, H740-H746.

51. Iafrati MD, Vitseva O, Tanriverdi K, et al. (2005) Compensatory mechanisms influence hemostasis in setting of eNOS deficiency. Am J Physiol Heart Circ Physiol 288, H1627-H1632.

52. Mukherjee TK, Nathan L, Dinh H, et al. (2003) 17-Epiestriol, an estrogen metabolite, is more potent than estradiol in inhibiting vascular cell adhesion molecule 1 (VCAM-1) mRNA expression. $J$ Biol Chem 278, 11746-11752.

53. Kockx MM \& Herman AG (2000) Apoptosis in atherosclerosis: beneficial or detrimental? Cardiovasc Res 45, 736-746.

54. Dimmeler S, Haendeler J, Galle J, et al. (1997) Oxidized low-density lipoprotein induces apoptosis of human endothelial cells by activation of CPP32-like proteases. A mechanistic clue to the 'response to injury' hypothesis. Circulation 95, $1760-1763$.

55. Dimmeler S, Rippmann V, Weiland U, et al. (1997) Angiotensin II induces apoptosis of human endothelial cells. Protective effect of nitric oxide. Circ Res 81, 970-976.

56. Vanhoutte PM (2009) Endothelial dysfunction: the first step toward coronary arteriosclerosis. Circ J 73, 595-601. 